\title{
Comparative Analysis of the Feature of the Process of Modernization of Vocational Education in China and Ukraine
}

\author{
Artem Samilo \\ Beijing Normal University, Beijing, China \\ Email: tyomasamilo@gmail.com
}

How to cite this paper: Samilo, A. (2019) Comparative Analysis of the Feature of the Process of Modernization of Vocational Education in China and Ukraine. Open Journal of Social Sciences, 7, 152-175. https://doi.org/10.4236/jss.2019.712012

Received: October 22, 2019

Accepted: December 6, 2019

Published: December 9, 2019

Copyright (อ 2019 by author(s) and Scientific Research Publishing Inc. This work is licensed under the Creative Commons Attribution International License (CC BY 4.0).

http://creativecommons.org/licenses/by/4.0/

\section{(c) (i) Open Access}

\begin{abstract}
A comparative analysis of the modernization of vocational education in China and Ukraine is of particular interest. First, in China, before the "cultural revolution", vocational education was organized according to the Soviet version and was oriented toward meeting the staffing needs of the state economy. Today, the Chinese government, based on the principle of "raising the country at the expense of science and education" and the strategy of continuous development, attaches priority to modernizing education and raising the cultural level of citizens. Recognizing education as strategically important for the country's socio-economic development, the Chinese government has developed a course in education: "In the development of education, facing modernization, the outside world, and the future." Secondly, in both countries, integration processes are actively developing in the education system, aimed at the formation of a single educational space for a professional school, production and science, and the elimination of the shortage of skilled workers and mid-level specialists. Thirdly, in Ukraine and China, the modernization of vocational education systems has set common strategic goals, due to the requirements of the labour market to improve the quality of training of the necessary qualifications, decentralization of management of the vocational education system and restructuring of vocational education institutions on the principle of optimization. Thus, the field of common interests in the study of vocational education in both countries can be identified. A major role in the current socio-economic situation was played by the popular tendency for compulsory higher education, as a means of increasing social status in society. And often this decision is made under pressure from established stereotypes and the older generation. At the moment, vocational education does not really fully satisfy and correspond to the needs of society and cannot solve the problems of training workers who are faced with new requirements for the level of
\end{abstract}


qualification and skills. Therefore, we observe a shortage of middle-level workers and specialists in technical, service and management work-the so-called blue and gray collar workers, who currently have the greatest difficulties in adapting to market relations and have the lowest income level. Therefore, in the current situation, it becomes an obvious and relevant decision to analyze the socio-structural factors and the mechanisms of their adaptation in the modern socio-economic environment, the formation of their professional structure. Also, consider and analyze the process of formation in the educational system of new trends which are expected from this sphere of education in modern economic conditions.

\section{Keywords}

Modernization, Reform, Innovation, Decentralization, Social Status, Vocational Education

\section{The Relevance of Research}

At the present stage in the conditions of accelerated social and economic development of the world community, further progress of science, technology and culture, each state increases the requirements for the vocational education system, content, forms and methods of education in vocational school, which is the sphere of reproduction and transmission of social experience due to the specific social-economic and political system.

Modernization of vocational education in the system of modern trends sets the Chinese and Ukrainian intelligentsia, in particular teachers, scholars, government and public figures, the task of training young people, which should be based on the best achievements of world and Chinese and Ukrainian pedagogical science, history and culture. Changes in market relations require significant changes in human consciousness. Since education lays the professional, psychological, social prerequisites for the development of the nation, its reforming is the first step towards the formation of a person of new thinking and the development of a knowledge society.

\subsection{Purpose}

The purpose of this work is a comparative analysis of the identified problems, the merits of vocational education and the improvement of workers' qualifications, as well as the identification of progressive trends in the development of the modernization of vocational training in Ukraine and China.

Analysis of recent research and publications. The studies of the development of vocational education in the modern conditions of China and Ukraine are devoted to the works of Ma Shutao, Tan Sonhua, Hua Yao Jiang, Dayueniyu, Cheng Xiwei, Yang Jitu, Lu Xun, Stewart, V, Jiang Xuanxing, Borevskayae, Severskaya LB, Belyayeva, A, Parsyak G, Radkevich, K.V. The authors investigated 
the peculiarities of the mutual influence of vocational education and the labor market, the innovative aspects of the development of vocational education, the didactic principles of vocational training and the organization of vocational training, the renewal of educational technologies used in vocational education.

\subsection{Tasks}

Based on the purpose of the study, the following tasks were set:

- Determine strategies for the development of vocational education in a single international educational space; to characterize the Ukrainian and Chinese vocational education system and to identify the main trends and principles of its modernization;

- To conduct a comparative analysis of the process of modernization of vocational education systems in Ukraine and China to establish the features and general trends.

The basis of economic progress is, first of all, people with certain personal, mental and professional qualities; as well as the nature of the political regime, the model of the economic system, the mechanism of legal regulation of all spheres of society.

Based on the analysis of the main legislative acts, analytical and statistical information in the field of education of the two countries, similar and distinguishing features of the functioning of vocational education systems in the field of state regulation, ideological base, financing, relations with production and roles in the economy were identified.

\section{Development of Modernization of Vocational Education and Their Sociocultural Effects and Trends in China}

Education is considered as the basis of movement along the path of socialist modernization, and the main goals of education are: to form pupils such qualities as patriotism, collectivism, loyalty to the course of socialism, ideas about the legal system of the state, about the national defense of the country, about the principles of national unity, satisfaction development needs of a socialist market economy and stimulate social progress. The ideological component of education is clearly defined: the ideas of Marxism-Leninism, Mao Zedong, the theory of building socialism with Chinese characteristics. Chapter II of the Law of the People's Republic of China on Education establishes compulsory nine-year education [1].

\subsection{Main Provisions}

The reforms launched in 1978 by Chinese politician and reformer Dan Xiaoping laid the foundation for building a modern vocational education system in China. Despite the fact that much of its history, China was one of the most developed countries in the world and the birthplace of outstanding discoveries, the country lacked a vocational education system. The basis of this was the following 
reasons.

In many ways, the development of education and the formation of the ethical and philosophical foundations of Chinese society were greatly influenced by Confucianism, whose main goal was the education of a moral person through education. Education was understood to mean the study of classical philosophy, history, literature, and politics. Confucianism did not recognize the preparation of a person for manual labor or the employment of applied sciences, regarding these aspects as things of a lower order in relation to classical disciplines [2].

The vocational education system in China is the largest in the world. It includes over 15 thousand professional educational organizations at the level of secondary and higher education and almost half of the total number of students enrolled at these levels [3]. Every year about ten million specialists graduate from vocational schools [4].

On September 1, 1996, the Law on Vocational Education, which applies to educational institutions of different levels and forms of vocational training, entered into force [5].

In recent years, the government has gradually built a regulatory framework and policies for the development of the labor market and vocational schools. In 2014, a plan was developed to build a modern vocational education system, which implies an increase in the number of students in vocational schools to 38.3 million people by 2020 (including vocational colleges-14.8 million students, vocational schools-23.5 million students). It is planned to make more than half of all higher educational institutions of the country professional, including by changing the profile of a number of universities to technical, and also to involve enterprises in the management of professional educational institutions. Such a need has matured for two main reasons. Firstly, it becomes more and more difficult for university graduates to find a job, while more than $80 \%$ of graduates of vocational education institutions are employed within six months from the date of graduation. Secondly, employers face the problem of filling blue-collar vacancies with a high level of qualifications. This situation emphasizes the need for the educational system of China to meet the requirements of the labor market [6].

At the government level, the issue of providing graduates of vocational schools with the opportunity to continue their studies at universities and receive degrees and diplomas available in the academic field is being worked out. This is also necessary to raise the status of vocational education and its recognition by the public.

In the field of vocational education, they are actively working to improve the skills of teachers and the quality of teaching. To fill teaching vacancies, it is allowed to hire part-time teachers, including from among the employees of enterprises. Teachers should attend refresher courses once every five years and work in the relevant industry for two months every two years [7]. In some provinces, incentive measures are being introduced for teachers of vocational schools, in- 
cluding the possibility of obtaining the title of professor.

Much attention is paid to the internationalization of vocational education as a factor in internal development. Unique historical, cultural, economic conditions of China's development do not allow borrowing foreign experience in the field of vocational education, which is why the country relies on a synthesis of the best practices of successful foreign vocational education systems, including the United Kingdom, Australia, Canada, USA, Germany.

At present, a new approach to the development of human capital is being developed in the country based on the development of the system of vocational education and training. Vocational education is an important component of the education system, and also contributes to the economic and social development of the country and the solution of issues related to employment. Economic and socio-demographic tasks are also assigned to the system of vocational education by the state. Through the development of vocational education, the development of rural areas, remote border and poor areas, and agriculture should be accelerated; assistance should be given to women, the unemployed, and people with disabilities.

\subsection{Features}

The features of Chinese vocational education are the connection with practical activities and orientation towards the needs of socio-economic development: vocational schools should combine education with practice, serve as the basis for building the economy, maintain close ties with enterprises and train staff. There is a very close relationship between institutions and enterprises, which should give vocational education in a planned manner for their employees. Enterprises are the basis for the practice of students in the system of vocational education.

The vocational education system, as one of the most important resources for ensuring the modernization of the economy, is to answer the main challenge of the country. The anthropological dimension of the cost of systemic transformations is, according to Chinese theorists (Ma Shutao, Tan Sonhua, Hua Yao, Jiang Dayan, Cheng Xiwei, Yang Jitu), in the qualitative transformation of the human potential of a country through the sociocultural design of optimal structural ordering of the vocational education system.

In the context of the above, the essence of the culture of administration and quality assurance of management decisions lies in the fact that the country has developed a national know-how of a cascading, multiplicative system of personnel training at (state) national enterprises, joint with foreign firms and private industries. At the heart of this management system are interdisciplinary training centers for vocational education, established in large national enterprises.

A multistage system that is effective in modern China, has an extensive system of incentives to receive education or advanced training (the dependence of the possibility of raising wages, increasing vacation time, partial payment by the enterprise of public services for its employees, etc., on the availability of education, 
academic status, high qualification.) is one of the examples of cascade control, achieving positive effects in the socio-cultural development of the country [8].

In China, a cascade system of personnel training at state-owned enterprises, joint with foreign (mainly with German) firms and private industries was developed and implemented. At the heart of the Chinese model of vocational education are interdisciplinary vocational training centers established at large national enterprises. This model is analogous to the German education system, which focuses on the use of practical, industrial sites. In Germany, the main classes are held in laboratories and workshops of the training centers of factories.

According to this scheme, China's largest automobile giant, the First Changchun Plant (FAW), was modernized. The success of FAW was the collaboration with the world's leading automakers, in whose training centers thousands of Chinese specialists underwent retraining.

Professional competencies are acquired by future specialists within the walls of vocational training centers of large state-owned enterprises, for example, the CES of the Changchun Automobile Plant. After working for the required time and not receiving complaints, the best specialists go for additional professional competencies to the internship sites of joint ventures, where they have to work for at least 5 years, otherwise they are obliged to compensate for the costs of their training in the PPS and at the internship sites. Since 1991, a number of enterprises with Volkswagen were created, in which, together with foreign experts, the modern Chinese auto industry was created, which by 2013 had reached such a level of development that the largest world fairs and showrooms held in Beijing and Shanghai are recognized by its level is often higher than European.

After working for 5 years, the best specialists are sent for internship to foreign automotive concerns of partner countries to obtain innovative competencies. Essentially, this on-the-job training scheme is a continuity of the life cycle of professional competencies with an innovative component. It should be noted that the subject of special attention from both the public sector in the face of industrial research centers and the private sector are specialists who have successfully completed their internships at foreign car companies. If a specialist leaves for private production, the latter are obliged to compensate for all his training and provide various bonuses in the form of high salaries, loans, etc. These specialists are expected to be able to implement new technological, marketing, production solutions, replacing copying foreign brands, common on this [9].

\subsection{Other Tasks}

- Development of multi-level, multidisciplinary and multifunctional secondary vocational schools;

- Improving the social image of the vocational education system; professional development of teaching staff;

- Development of social partnership of vocational school with production; regulatory support of raising the social status of vocational education teach- 
ers and support for low-income students enrolled in the vocational education system;

- An increase in the share of practice-oriented training through the creation of vocational education at educational institutions of its own base of practices;

- Maintaining professional standards [5].

The decision of the State Council to accelerate the reform and development of vocational education states that "in the near future it is necessary to make every effort to create a modern system of vocational education that meets the needs of a market economy, a labor market and employment [10]. It is necessary to create an appropriate structure for the normal functioning of this system, to have flexibility, openness and independence." The government has defined requirements for the vocational education system, which includes a comprehensive improvement in the quality of the workforce, its compliance with the economic structure and level of technological development. To achieve these goals, the development of vocational education should be focused on the solution of the following task: the training of skilled and highly skilled workers [10].

In the coming years, the system of vocational education in China plans to prepare 22 million graduates of secondary vocational schools and 8 million graduates of colleges of higher vocational education. Each year, about 3 million people who have lost their jobs must undergo retraining, and another 50 million urban workers need to upgrade their skills in the vocational education system [11].

The Government has identified the use of information technology in vocational education as a priority. The Ministry of Education considers modern distance education to be a priority for development. There is a need in the country to introduce information technology, television, radio and the Internet to create a national network of modern distance education, which will cover remote areas. The government is embarking on a number of projects related to distance education and is increasing investment in distance professional education projects. And also new training programs for computer networks are being developed to help centers for the training of skilled workers, where with the help of training course software, video projects, videotapes, to improve the quality of training [10].

It also increases the role of enterprises in the development of vocational education, which should carry out training in accordance with real demand, improve the system of vocational training of workers in specialized specialties. In order to interact with educational institutions and participate in the adjustment of vocational education, enterprises need to provide opportunities for practical training on their territory. Some enterprises can independently or cooperate with higher educational institutions to create vocational and technical colleges.

\subsection{Sources of Financing}

The main sources of funding vocational education in China are: 
- State-financing is carried out on the basis of the average cost per student;

- Enterprises-pay the costs of vocational training for those who are planning to hire and their employees;

- Local taxes;

- Student fees;

- Social contributions;

- Incomes of vocational educational institutions received as a result of the provision of services to enterprises.

Despite the numerous options for the development of the vocational education system, at present its financing depends mainly on the state budget. And the main problem of financing vocational education is a small amount of allocations provided for by the state budget [12].

The special features of the modernization of the vocational education system in China include:

- Multi-channel financing of the vocational education system; development of social partnership of vocational schools with domestic and foreign enterprises on a mutually beneficial basis;

- An increase in the share of practice-oriented training and the creation at educational institutions of vocational education of their own databases of practices equipped according to the requirements of modern production;

- Implementation of state support for students from low-income families in obtaining vocational education;

- Improving the social status and improving the socio-economic conditions of life for vocational education teachers [5].

In China, before the "cultural revolution", vocational education was organized according to the Soviet version and focused on meeting the staffing needs of the state economy.

Today, the Chinese government, based on the principle of "raising the country through science and education" and a strategy of continuous development, attaches priority to the modernization of education and raising the cultural level of citizens.

Recognizing education as strategically important for the socio-economic development of the country, the Chinese government has developed a course in the field of education: "In the development of education, we face modernization, the outside world, the future" [5].

\subsection{Problems}

Since 2002, the issue of problems of vocational education has been the subject of numerous special and professional conferences under the auspices of the State Council of the PRC. The first of these in July 2002 was an educational conference, the documents of which were published under the title "The State Council actively promotes the reform of the development of vocational education". This conference was held at the very beginning of the twenty-first century, when the 
problematic and contradictory nature of vocational education was faced with numerous difficulties, problems and challenges in the development of an innovative economy of the country.

Traditionally, manual workers in China receive low wages, poor treatment and do not have any opportunities for social and professional advancement, so the Chinese do not seek a voluntary choice of vocational education. Choosing an educational institution, Chinese parents would prefer to send their child to a simple high school or even a paid non-state educational institution than to make a choice in favor of the technical school, even if it is good, it proved itself [13].

One of the significant factors that determined the attitude of the Chinese to vocational education was the idea of personal reputation, which undoubtedly is one of the typical, traditional features of Chinese psychology and culture.

The Chinese greatly value their "personal reputation" and "good name". Famous Chinese writer Lu Xun astutely notes that reputation is the guiding moral principle of Chinese traditional culture. In the traditional Chinese understanding, "personal reputation" to a greater degree expresses universal recognition and position in society, which a person acquires due to his achievements [14]. By "personal reputation" is meant the progressive "ascent" of a person throughout his life, which is the result of both public opinion and hard work and incessant self-development. The notion of "personal reputation" contains a person's aspiration for self-exaltation and exaggeration of one's own importance in the eyes of other people.

"Personal reputation" in the Chinese sense is what other people can say and think about in a given situation [15].

The expression "ten years by the cold window" is widespread, which meant a long, stubborn and unbroken study, building on books in order to, after going through difficulties and hardships, to rise above other people, to rise above the masses and manage it. Therefore, the division into two main categories of the population-officials, managers and simple people, subordinates, is a key element of Chinese culture. Delving deeper into history, we find the mention of this complex social structure in Li Ji [15].

The study of the main provisions of the strategy of the national ideology of modernization of vocational education in China makes it possible to analyze the established indicators of the effectiveness of cultural modernization and the culturally and socially significant effects obtained, which indicate that the main subject of cultural modernization is overcoming the traditional ideas about the low importance of vocational education and creating a new image of workers professions. The national ideology of modernization of vocational education in China includes: a corpus of documents, measures to attract the population and a set of measures to ensure the effectiveness of these measures [16].

\subsection{Future Vision}

The process of globalization causes the need for professional personnel of the new level. 
Promotion of the development of vocational education in general has become particularly relevant, since the quality and scale of vocational education are becoming decisive factors for the modernization of industry and agriculture.

After a large-scale discussion of the problem in the context of the general policy of reform and openness, the ideologists of the country decided to adopt a special policy aimed at introducing modern achievements and advanced experience of modern production into the vocational education system and the Law on Vocational Education in the People's Republic of China. Based on the analysis of the new situation, new tasks of the vocational education system in foreign countries and new problems of vocational education in China, a special committee was created and a strategy was adopted.

"Enhanced development of vocational education" in the country, ensured a massive involvement in the modernization process.

In July 2010, the main principles of the Program for the Long-Term Development of the Education Reform of the PRC were published, which marked the beginning of the current stage of development of the vocational education reform in the country. The reform ideologists proceeded from the main goal of the program: to build a modern vocational education system for the country to enter a new stage in the development of a culture of an innovative society. 4 main objectives of the implementation of vocational education reform are formulated:

- Construction of a modern vocational education system;

- Creation of cooperation mechanisms in the field of education with enterprises on the basis of innovation;

- Update the system of management of vocational education in the situation of systemic changes;

- Development of a social justice system [17].

The Chinese education market is becoming attractive for international cooperation against the backdrop of a powerful economic, political, cultural and educational uplift of the PRC. Chinese institutions not only higher, but also secondary vocational education have cooperation agreements with the Russian Federation, the United States, Germany, Great Britain and other countries, adopting their experience. A three-year intergovernmental agreement on cooperation in the field of vocational education (PO) has been concluded with the UK ([16], p. 118).

In the US, there is also a similar trend towards expanding ties with universities in China. Scientists have concluded that the internationalization of education is already becoming the main direction of the future development of education in the PRC ([18], p. 19).

The internationalization of vocational education is one of the key resources for improving the competitiveness of vocational education institutions in the educational services market; it is especially significant for Chinese vocational education institutions in general and for their regional segment in particular. The regional vocational education institution should provide in its region points 
of growth and opportunities for advanced development, facilitate the implementation of promising projects, technologies and industries ([19], p. 16). In 2014, the "Resolution of the State Council of the People's Republic of China on the Acceleration of the Development of Modern Vocational Education" was published, which provided for the following goals of the internationalization of vocational education in China:

- Improving the joint cooperation mechanism between China and foreign countries;

- Attraction of foreign high-quality educational resources and high-level specialists;

- Facilitating the exchange of teachers and students between Chinese and foreign professional educational institutions [17].

Cooperation with foreign countries contributes to the quality of vocational education. It is carried out at different levels using various forms and methods.

Thus, the city center of vocational training "Taitsan" together with one of the German enterprises created the Center for the training of technical specialists, which uses the German model of training. Graduates of this center are in special demand on the labor market: enterprises that want to get them pay several hundred thousand yuan for each.

The Suzhou Industrial Park Technical Institute created its own training model, based on the concept and experience of the Singapore Nanyang Polytechnic Institute: "high-class training, modular training, and management of the board of directors".

Suzhou Vocational College of Tourism and Economics adheres to the international concept of open education. In 2004, in conjunction with the Australian Institute of Hotel Business, he introduced a new specialty, "International Class Hotel Management," fully adopting the Australian model of personnel training. The students had the opportunity, without leaving the country, to study the foreign experience of hotel management, as well as the opportunity to study abroad with the bachelor's and master's degrees. These projects have been recognized and supported by the provincial and city governments [18].

In addition, international cooperation allows teachers to be sent for internships abroad, which contributes to an increase in the general level of vocational education.

Rizhao is a new developing coastal city in the Shandong province of China, where software began to develop from scratch and has reached a certain scale today; the first steps have been taken to create a network of higher and middle software with favorable prospects for development. Today, more than $60 \%$ of secondary vocational education institutions (secondary vocational education) Rizhao have established cooperative relations with foreign partners, this has opened up new international development prospects.

Together with the Hong Kong Vocational Training Council, Ningbo Polytechnic College launched a pilot program in electronics and today has the right 
to issue a certificate in electronics. The system of study programs from Hong Kong, applied according to international standards, was created to enhance the skills and abilities of students.

A successful international strategy for an institution of vocational education is a resource for increasing its competitiveness, an additional source of funding, a factor in increasing national and international prestige.

\section{The Condition of Professional Education in Ukraine}

\subsection{Main Provisions}

The fact that it is under the control of the government of Ukraine testifies to the significance of the problem of training and raising the level of workers' skills in enterprises. So on April 7, in 1998, the Cabinet of Ministers of Ukraine adopted a resolution on the creation of the Intersectoral Council for Vocational Education [19].

According to Article 15 of the Law, the purpose of vocational (vocational) education is the formation and development of professional competencies of a person necessary for professional activity in a particular profession in the relevant industry, ensuring its competitiveness in the labor market, mobility and career prospects throughout life. Professional (vocational) education is acquired on the basis of basic or complete secondary education [19].

Modernization of vocational education in the world is based on the normative-legislative acts and declarations of the Bologna and Copenhagen processes, which determine the main strategies for the development of vocational education:

- Improving the quality of vocational education, as one of factors of interaction of supply and demand in the field of professional education;

- Development of student and graduate student mobility education;

- Development of social partnership in the field of vocational education, ensuring its flexible and rapid response to rapid changing labor market needs;

- Increasing the attractiveness and image of vocational education through the provision of various grants and scholarships to students of institutions vocational education;

- Providing graduate employment vocational education institutions; opening for graduates prospects for study and career.

Integration of the vocational education system into the world educational system is one of the priority tasks of the educational policy of the Russian state. Ukraine joined the Bologna process in 2005.

This is due to the fact that in the modern world, national security and independence of states are inseparable from the level of their technological development. The role and importance of each country in the global economy is directly dependent on how high-tech it is. The level of development of high technologies at present is a characteristic of the economic state and scientific productive capacity of the country and ensures its competitiveness. The main capital of 
any state is human capital. The leading idea of the modernization of vocational education in Ukraine is the orientation of the potential and resources of vocational institutions education on the final result-professional development and self-development of specialists.

The main directions of modernization of vocational education in Ukraine are:

- Regionalization of vocational education management;

- Differentiation of vocational education institutions by types and types; standardization of vocational education;

- Development of social partnership of vocational education institutions with production;

- Profiling of education in the senior classes of the secondary school, ensuring continuity between general and vocational education [20].

\subsection{Features}

Obtaining vocational (vocational) education on the basis of basic secondary education is carried out with the simultaneous receipt of specialized secondary education and the receipt of the relevant document on complete secondary education.

The system of vocational schools is a three-tier system of training.

The same article (15) defines the levels of vocational education: the first (initial) level; second (basic) level; the third (highest) level [19].

Each degree of study is determined by theoretical and practical completeness and is fixed by assigning the appropriate qualifications to graduates. Graduates of the lowest degree of their own free will can continue their studies at the highest.

"High-quality vocational education is possible under the condition when there is modern equipment, an innovative teacher and a qualified master. For a long time, investments in vocational education were limited, which led to a decrease in the prestige of this area among Ukrainians. However, today we must approve the opinion that-technical education is not a form of social protection, but a real economic investment in a person"-Pavel Khobzei, Deputy Minister of Education and Science [21].

\subsection{Current State}

Vocational education enrolments are falling for work.

Minister Hrynevych said the establishment of multi-functional VET centers will help to meet the skills. The centers take a holistic approach, offering different levels of vocational education, including adult learning. Ukraine is working together with employers to promote work-based learning and apprenticeship. It is modernizing occupational and educational standards, in-line with labor market needs and technical support, EU and international partners.

Dmytro Oliynyk, President of the Federation of Employers in Ukraine, "We are a dream of an integrated vocational education and training system, closely related to companies. We need to unite our efforts". 
The vision contributes significantly to public policy debate. It puts education, training, lifelong learning, entrepreneurship, i.e. the entire skills system, at the center of economic reform [22].

\subsection{Financing}

In Figure 1, we can see the Functional classification and the volume of expenses for vocational education from the state budget. Such a subvention from the state budget was a significant resource for supporting vocational education in Ukraine. However, the laws of Ukraine "On the State Budget of Ukraine for 2016" and "On Amendments to the Budget Code of Ukraine" funded institutions of vocational education transferred from the State Budget to the corresponding local budgets. At the same time, the provisions of the subvention for the training of labor personnel were withdrawn from the Budget Code of Ukraine, which, in turn, substantially reduced the resource base for the financing of vocational education. In addition, the Law of Ukraine "On the State Budget of Ukraine for 2016" provides for transfer of state-owned property to the communal property of vocational and technical educational institutions [23].

The main goal of the changes introduced was to achieve the decentralization of vocational education, which in turn would help to optimize expenditures on education through reorientation to the needs of the regional industry. Since 2016, a new subvention for the modernization and updating of the material and technical base of vocational schools has been introduced, the distribution of which is approved by the local budgets in the Law of Ukraine "On the State Budget of Ukraine for 2016. The procedure and conditions for the provision of this subvention were approved by the relevant Decree of the Cabinet of Ministers of Ukraine [24].

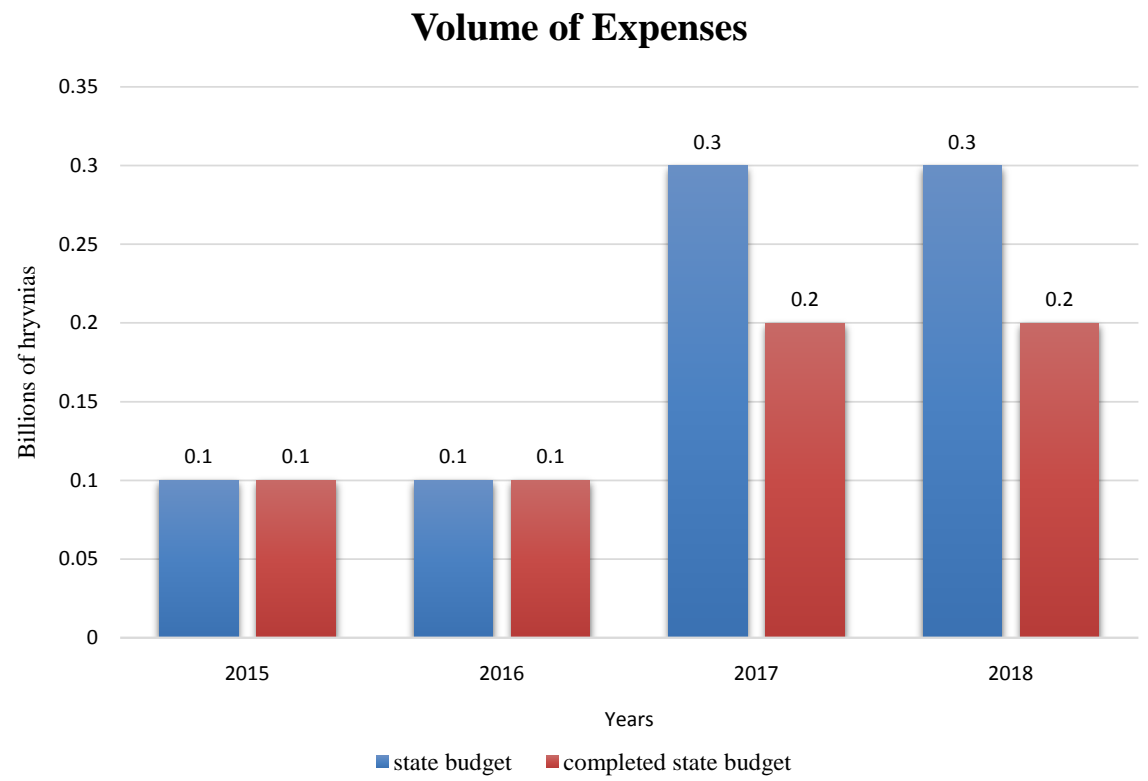

Figure 1. Volumes and structure of financing vocational education in Ukraine in 2015-2018. Source: Sovereign Treasury Service of Ukraine. http://www.treasury.gov.ua [23]. 
Today, vocational education is financed mainly from local budgets, taking into account the implementation of the financial decentralization reform in the country and increasing the resource base of local budgets. However, according to the Ministry of Education and Science, these funds cover only slightly more than $60 \%$ of the financial needs of educational institutions in the regions. Vocational schools located outside the cities of oblast importance are in a worse position, since the current financial mechanisms cover their needs by only $45 \%$. This is stated in a joint study by the European Foundation for Education and the Ministry of Education and Science of Ukraine [25]. Also, in May 2018, the Ministry of Education and Science developed a draft conceptual framework for the reform of vocational education in Ukraine "Modern professional education" [26]. This document explains the ideology of changes in vocational education and training and should define the consolidated goal, objectives, development paths and key components of modern vocational education. In the context of decentralization, the concept implies:

- An effective model of management of vocational education with the transfer of real powers to regions, personnel customers and ensuring the autonomy of vocational education institutions for reformal change;

- A new structure and an optimal network of vocational education institutions that respond quickly to the needs of the labor market, takes into account personal needs, provides lifelong learning and professional qualifications;

- Multi-channel financing of vocational education institutions in accordance with well-defined volumes, directions and levels of training of skilled personnel, implementation of investment projects for the modernization of vocational education.

In Ukraine, the special features of the modernization of the vocational education system in turn include:

- Guidelines for referencing qualifications for qualifications, competence, orientation, training modules, occupational qualifications;

- Development of national vocational education and training standards in select occupations requiring formal training;

- Recommendations for the social partners;

- Development of quality assurance indicators for vocational education and training [27].

\subsection{Problems}

The process of financial decentralization in the country is not without problems.

The money of local budgets should be used more effectively, as of 01.12.2018, on deposits in banks placed 12 billion UAH. Of these, UAH 6 billion, this is money from regional budgets. More details about this information can be found in the investigated Office of Financial and Economic Analysis in the Verkhovna Rada of Ukraine [28]. The volume of expenditures on vocational education needs to be increased in line with the needs that have arisen in this area. Funding 
should be multi-channel, that is, from several sources, including the attraction of the subvention of the state budget of Ukraine.

At the same time, the study leads to the conclusion that, despite some innovations in vocational education, the situation in this area in Ukraine cannot be considered fully satisfactory, which provokes in the future a number of socio-economic problems, one of which is the youth unemployment. The high unemployment rate of young people in Ukraine is due to the fact that a significant part of young people do not have the appropriate professional skills and experience, in addition, according to the State Statistics Service of Ukraine, the inconsistency of demand and supply in the labor market is deepened (Table 1).

Thus, it is obvious that reforming education is one of the priorities of the state personnel policy. In the context of the internationalization and globalization of the world's economic, social and labor spheres, Ukraine should not be left behind educational reforms carried out abroad.

Domestic and foreign experience proves that the reform of the economic mechanism in the state almost always accompanies the reform of education. At the same time, it is advisable to carry out reforms in the direction of overcoming the problem factors in the field of vocational education, the most significant of which are for Ukraine as follows: the quality of education does not meet the demands of employers, the number and specialization of graduates do not meet the needs of the economy, the education system does not fully form graduates. Competitive skills are important for the competitiveness, and the funds allocated to education are not spent efficiently, educational institutions lack financial and academic

Table 1. Indices of supply and demand supply imbalance Ukraine in 2016 [29].

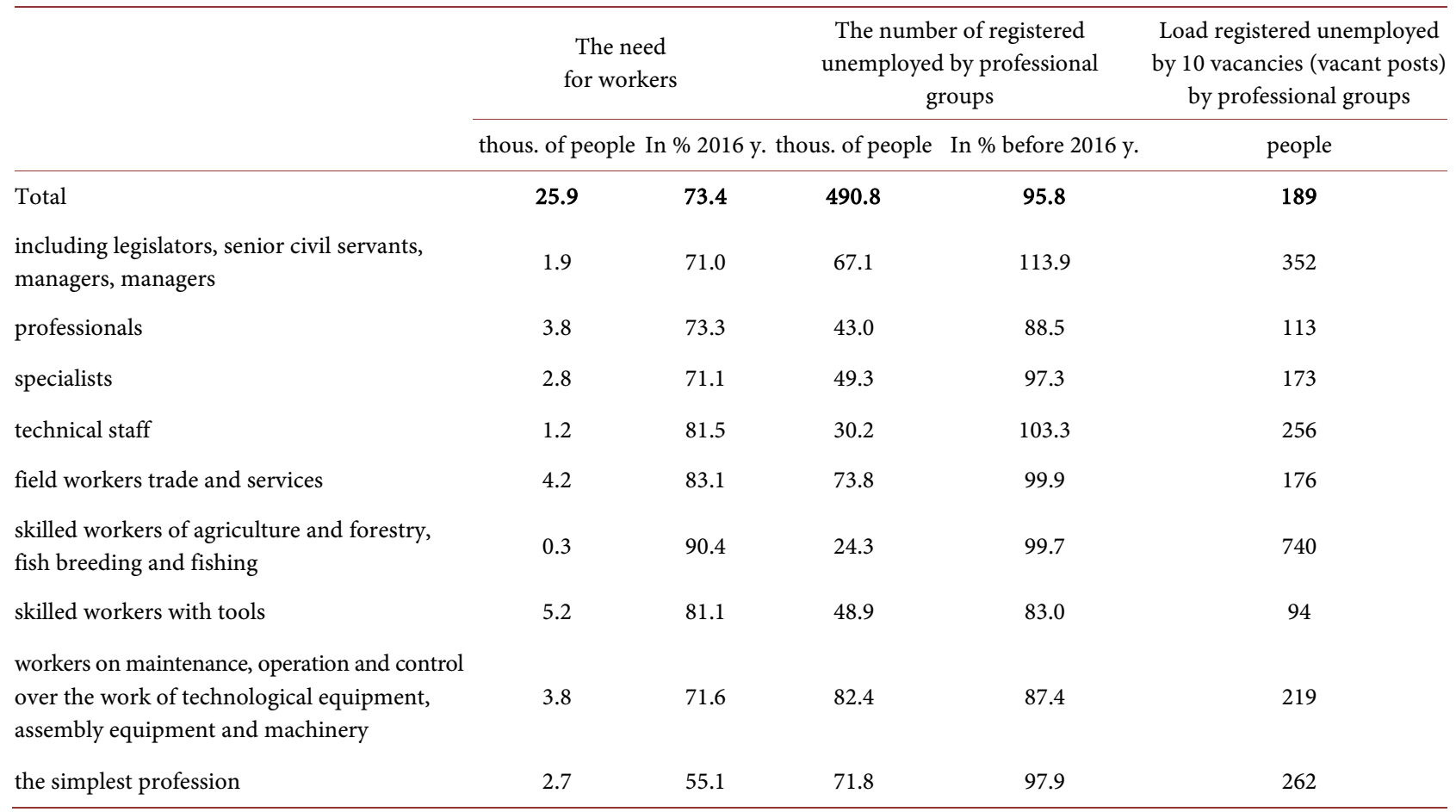

Source: State Service of Analytics and Statistics of Ukraine, data of personnel and information agencies. https://www.dcz.gov.ua/analitics/vie [29]. 
autonomy, there are shortcomings in planning and vocational education, companies almost do not invest in staff training, etc. [30].

In order to reform the education system, improve its quality and ensure that the challenges of time are met in Ukraine, certain steps are being taken. In particular, the Law "On Professional Development", which defines the legal, organizational and financial principles for the functioning of the professional development of employees, was adopted in 2012, which is important for the effective implementation of the state personnel policy in Ukraine and the development of the system of vocational education. Given its importance, we also note its problematic points-it does not directly provide for the allocation of public funds for the professional development of employees and does not clearly determine the amount of funds that the employer has to focus on professional development. In our opinion, this can be seen as a deterrent, as most employers and workers are limited in their available resources, which can be earmarked for professional development, and some employers who have sufficient funds are not fully aware of the feasibility of investing in staff development [31].

\subsection{A Future Vision for Vocational Education}

Ukraine's Education Minister Lilia Hrynevych and EU Delegation's Head of Cooperation Berend de Groot joined ETF experts, parliamentarians and stakeholders from the worlds of work and education to discuss the future of vocational education and training (VET) on February 22, 2018 in Kyiv.

- EU best practice from Finland and Ireland was also shared. The outcomes will help shape the future vision.

- The EU's commitment to boost skills and education, "We want to see economic growth in the country and for that we need skills".

- The responsibility for vocational education is being devolved to the 25 regions-a major challenge for a country of 45 million.

- Working closely with Ukraine as a driver for its education and skills agenda, bringing the system closer to European standards.

- Decentralization is a complicated process, due to the "completely new system of governance", she said, "Decentralization represents a lot of challenges but at the same time it provides opportunities."

- Regional VET Councils are being established to support skills intelligence in labor market needs and shape regional policy approaches. The financing of vocational education is another focus area [27].

(The European Training Foundation is a European Union agency that helps transition and developing countries to capitalize on their human capital through the reform of education training and labor market systems.)

The project of conceptual foundations "Modern professional education" of the Ministry of Education and Science May 22, 2018.

- The department is confident that vocational education should be popularized among entrants, since now only $14 \%$ of Ukranian school graduates receive 
vocational education, while the rest are oriented to higher education. The Ministry of Education notes that in Europe this figure is $40 \%$, while in the Czech Republic, Croatia, Austria and Finland-70\% and more.

- To create a new image of vocational education, as well as to improve the skills of workers in each region, promise to open multifunctional centers of professional excellence. At their base, they will be trained in high-tech professions and provide professional higher education. Future centers should become a platform for cooperation between VET institutions, local authorities and employers.

- Funding for training is planned to be carried out from several sources-local and state budgets, funds of private individuals and enterprises. The possibility of using grants or charity assistance is also separately identified [21].

The document will become the basis for the concept of vocational education.

- "Vocational education should be financed from the regional budget, because the localities are better at understanding and knowing what kind of personnel there is not enough for the region. All this is provided for by the decentralization reform, but among other sources of funding we offer support from the state budget for professions of national importance. We are planning to expand this list in September, and we can also consider the resources of other ministries and departments that are customers of certain professional services" Hobzai noted.

For the sake of matching vocational training with labor market demands, they will introduce a component of social partnership. His key participant will be the employer who forms professional standards and helps in the implementation of dual education (getting education in the workplace). The partnership will also recognize non-formal and informal education.

They want to improve the quality of education due to the modernization of the educational environment, the attraction of employees from the production and services sectors, and the promotion of the professional development of the teachers of the institution. It will also create the necessary training conditions for people with special educational needs.

General tendencies of the process of modernization of vocational education systems in China and Ukraine

On the basis of the analysis of the vocational education system of each country, general tendencies and features of the process of modernization of vocational education in Ukraine and China are revealed.

In Ukraine and China, before the modernization of vocational education systems, general strategic goals are set, due to labor market demands for improving the quality of training of the necessary qualifications, decentralization of the management of the system of vocational education and the restructuring of vocational education institutions on the principle of optimization. Thus, the field of common interests in the study of vocational education in both countries can be identified: 
- Formation of normative and legal support for the reform of vocational education;

- Decentralization of vocational education management;

- Raising the social image of primary and secondary vocational education;

- Development of social partnership of vocational school with production;

- Raising the level of training of specialists in accordance with the requirements of the labor market;

- Formation of a modern system of training pedagogical personnel for the system of vocational education;

- Strengthening the material and training base of vocational education institutions and creating a system of financial support for students and teachers;

- Differentiation of institutions of vocational education by types and types.

Comparative analysis of the modernization of the vocational education system in Ukraine and China allowed to identify common problems.

First, the backlog of the content of vocational education from the needs of the market labor, world economic development strategies. The market for educational services is a specific kind of market in a mixed economy based on a variety of forms of ownership and, accordingly, sources of financing education, science and industry. The market for educational services arises and functions along with and in cooperation with the labor market, which largely determines the structure of demand for educational services, primarily due to the individualization of requirements for the level and quality of education of specialists from numerous employers.

Secondly, it is a sharp deformation of the structure and volume of training personnel that is clearly not relevant to the real needs of the labor market, which creates a shortage of workers and specialists with secondary special education.

It is necessary to ensure the high quality of training necessary qualifications, first of all, highly skilled workers. This requires the development of a forecast of the need for workers and specialists taking into account the real demands of the labor market and the development trends of promising directions of the economy.

Thirdly, the problems of business reputation and social status in recent years have become universally recognized. Of course, one cannot but note the current positive change in this matter.

But the problem of low popularity among the young population and a positive attitude towards it among students, teachers, adults and parents is still especially relevant.

The study showed that to solve problems it is advisable to take the following series of measures:

- Creation of federal and regional forecasting systems and monitoring of current and future labor market needs in personnel various specializations and qualifications, including taking into account the global trends;

- Formation of legislative base for the organization of the system partnerships of the state, production, business and vocational education, which involves 
the active participation of employers and their associations in the innovative development of vocational education;

- Improvement of the nomenclature of professions and specialties, optimization of directions training at all levels of vocational education in accordance with modern requirements;

- Structural and institutional restructuring of vocational education, optimization of the network of its institutions, development of a new typology of educational institutions;

- Transition to the modular principle of the construction of educational programs of professional education, which will ensure its flexibility and variability, personal orientation, adequate compliance with the demands of the labor market;

- Widespread use of new educational technologies, including technologies "Open education", interactive forms of education, project and other methods that stimulate the activity of students, formulate skills of information analysis and self-study, increasing the role of self student and student work;

- Development and introduction of per capita regulatory financing of professional education institutions of all types and levels;

- Development and testing of various models of regional management of vocational education;

- The creation of a modern, mobile and flexible system of continuing professional education (as an integral part of parts of the general system of continuous education), including all levels of vocational education-from primary to postgraduate.

On the features of modernization of vocational education system of Chine can be attributed to:

- Development of multi-level, multi-profile and multifunctional secondary vocational education institutions;

- Increase the social image of the vocational education system;

- Increase qualifications of pedagogical staff;

- Development of social partnership vocational school with production;

- Legal and regulatory support increasing the social status of vocational education teachers and support for low-income students studying in the professional system education, increasing the proportion of practice-oriented preparation through the establishment of a vocational education at the educational institution of its own bases of practice;

- The introduction of professional standards.

In Ukraine, the features of modernization of the system of professional education comprise:

- Continuity and standardization of professional education;

- Profiling of education in high school of general education;

- Integration of education, science and production;

- Financial decentralization and local government. 


\section{Conclusions}

The following conclusions can be drawn from the analysis of the main legal acts of Ukraine and China in the field of education. For both states, education is a priority area. Education has significant social, economic, political, ideological, cultural, and even strategic functions. In Ukraine and China, professional education is a right, and this right is guaranteed by the state.

In both Ukraine and China, the basic constitutional approaches to compulsory general education are the same. In many ways, the education systems themselves are similar. Highlighted vocational education includes secondary vocational education as a level of vocational education. In both countries, attention is paid not only to vocational education, but also to vocational training, the use of modern teaching methods is encouraged.

In China, the levels of vocational education are primary, secondary and higher vocational education (by analogy with the system that operates in Ukraine).

The principal difference between the compared systems is that in China the other levels of education after the mandatory nine-year period (secondary, vocational, higher) are paid. The Constitution of Ukraine guarantees free vocational education, although there is a commercial form of education.

The ideological, patriotic and labor components are strong in China's education. The Chinese education system is characterized by the principle of shared responsibility, which is manifested at all levels, and the mode of multi-channel financing of education (state, parents, enterprises, private investors, funds, etc.).

Comparative analysis of the modernization of the vocational education system in Ukraine and China showed that to optimize the reform of the professional education in China, it is advisable to use the Ukrainian experience. First, it is the standardization of vocational education. Educational standard is the norm, mandatory for each school specific specialty. The standard sets on behalf of the state the main objectives and the educational content of the future specialist in a vocational school. State educational standards are the basis objective assessment of the level of education and qualifications of graduates independently from the forms of education. Introduction of state educational standards provides the state with the role of customer specialists.

Secondly, it is the formation of the pedagogy of vocational education, as a system of interdisciplinary scientific knowledge. Scientific integration knowledge in studying the problems of professional pedagogy is due to that education today is one of the most important factors for sustainable development of society, competitiveness and national security of the state.

To optimize the process of modernization of vocational education in Ukraine may be interested in the experience of Chinese vocational education multi-channel financing of vocational education institutions, development of mechanisms for attracting extrabudgetary funds, creating conditions for investment attractiveness vocational education system, the formation of a positive image vocational school teachers. Thus, the results of the study confirmed the hypothesis and allowed draw the following conclusions: 
1) In the modern world, national security and independence of states inseparable from their level of technological development. Role and importance each country in the global economy is in direct proportion to how much she owns high technology. Study of the state of education economically strong European countries allows us to state that the competition of countries in the economic field comes down to fighting for primacy in the field of science and technology, therefore, competition in training highly qualified technical specialists, competent in the field of solving system practical problems. Development strategies vocational education is in a single international educational space due to the rating of the countries of the world community.

2) The development of vocational education in Ukraine is in three main areas.

Directions:

- Socio-economic (definition of strategic objectives of vocational education, its impact on the national economy, social structure and social development of society, financing vocational education systems, ensuring social security for its employees and educational institutions);

- Technological (development of new educational technologies, the creation of appropriate material and technical the base and its infrastructure, scientific and methodological support and enhancement of the competence of workers in the vocational education system);

- Pedagogical (the solution of private educational and educational tasks that contribute to unleashing students' potential, their self-knowledge, self-realization and self-determination).

3) Modernization of vocational education as a factor of strategic development country is a primary concern for the PRC. Education can no longer limited to "pulling up", it should work ahead of the curve. In new socio-economic conditions, educational institutions are increasingly at least they exercise their rights in terms of academic and economic autonomy, expand the range of educational and other services provided population and enterprises of various organizational and legal forms.

4) In the situation of the vocational education systems Ukraine and China, the problem arise the question of finding the optimal strategy for their implementation. In this regard, it is not only advisable, but necessary, appeal to the personal experience of each other's development and reform vocational education in other countries with developed market economies. This will allow, if not to avoid, then minimize the possible negative consequences and mistakes as well as compare your own political decisions with the experience of others and thus better assess the feasibility and risks of their adoption.

\section{Conflicts of Interest}

The author declares no conflicts of interest regarding the publication of this paper.

\section{References}

[1] Constitution of the People's Republic of China [Electronic Resource]. 
http://chinalawinfo.ru/constitutional_law/con-stitution

[2] Wang, A. (2011) Dual System and Progressive Education System. The Florida State University, Tallahassee, FL, 63 p.

[3] Stewart, V. (2015) Made in China: Challenges and Innovations in Vocational Education and Training System. International Comparative Study of Vocational Education Systems. National Center on Education and Economy, Washington DC, 44 p.

[4] NPC (2015) China Learns to Love Vocational Education. 24-31.

[5] Vocational Education Law of the People's Republic of China [Electronic Resource]. http://en.moe.gov.cn/Re-sources/Laws_and_Policies/201506/t20150626_191390.html

[6] Yang, P. (2014) Understanding Vocational Education Market in China. CEREC WP, $33 \mathrm{p}$.

[7] Lai, R.-Z. (2011) Vocational Education and Training in China. Introduction to Chinese Policy, 716.

[8] Malyavin, V. (2005) China Managed: Good Old Management. M.: EUROPE, 304 p.

[9] Jiang, X.Y. (2013) Research and the Search for Creating a System of Training Highly Qualified Specialists in China and Russia. Proceedings of the Intern. Forum "Modernization of Vocational Education in China, Russia, Mongolia". ZabGU, Chita.

[10] Jiang, X.Y. (2009) Main Trends in the Modernization of Vocational Education Systems in China and Russia. 15.

[11] Information and Analytical Materials of the State Duma [Federal Assembly of the Russian Federation]. http://iam.duma.gov.ru/node/8

[12] Mashkina, O.A. (2004) Vocational Education in the PRC: Study Guide. M.: MAX Press, 93 p.

[13] Ivanova, Y.V. and Sereda, A.V. (2012) Material Welfare in the Traditional System of Values of Chinese Society. Chita, 86, 95-102.

[14] Lisevich, I.S., Burov, V.G. and Vyatkin, R.V. (1973) Li Ji: Ancient Chinese Philosophy. Collection of Texts in 2 Volumes. 99-140.

[15] Shaughnessy, E.L. (1999) Western Zhou History. In: Loewe, M. and Shaughnessy, E.L., Eds., The Cambridge History of Ancient China: From the Origins of Civilization to 221 B.C., Cambridge University Press, Cambridge, 292-351. https://doi.org/10.1017/CHOL9780521470308.007

[16] Guo, X., Gomboeva, M.I. and Zamoshnikova, N.N. (2013) Cultural Heritage and Socio-Cultural Factors Defining the Problems of Modernizing Vocational Education in China. Scientific Notes of ZabGU, No. 4, 170-179.

[17] Jiang, X.Y. (2009) The Main Trends in the Modernization of Professional Systems Courses in China and Russia. Kazan, 15 p.

[18] Zhang, Y. (2010) Strategic Thinking of the International Development of Vocational Education-Based on the Analysis of the Suzhou Higher Vocational and Technical College of Tourism and Economics. Soochow University, Soochow, 18.

[19] Constitution of Ukraine [Electronic Resource]. https://zakon.rada.gov.ua/laws/show/

[20] Burik, M. (2009) The Bologna Process in the World and in Ukraine.

[21] Ministry of Education and Science of Ukraine [Electronic Resource]. https://mon.gov.ua/ua

[22] The Federal Institute for Vocational Education and Training Is an Independent Institution Established under Public Law [Electronic Resource].

https://www.bibb.de/en/26525.php 
[23] Sovereign Treasury Service of Ukraine (2015) 10 Law of Ukraine "About 30 State Budget of Ukraine for 2016 Rick" from 12/25/2015 Viii. 11 Law of Ukraine "On the introduction of a law to the Budget Code of Ukraine" from 12/24/2015 to the rock number 911. http://zakon.rada.gov.ua/laws/show/928-19 http://zakon.rada.gov.ua/laws/show/914-19

[24] Positions to the Cabinet of Ministers of Ukraine. On the Consolidation of the Order and Minds of the Subvention from the State Budget to the Budgets for Modernization of the Material and Technical Base of the Professional and Technical Foundations.

[25] Financial and Economic Analysis Office in the Verkhovna Rada of Ukraine, 2019.

[26] The Ministry of Science and Science of Ukraine. The Ministry of Education and Science (MES) Developed a Project of Conceptual Ambushes for the Reform of the Ukrainian Academy of Sciences "Such a Professional Academy".

https://mon.gov.ua/ua/news/mon-rozrobilo-proekt-konceptualnih-zasadreformuva nnya-profesijnoyi-osviti-ukrayini-suchasna-profesijna-osvita

[27] The European Training Foundation is a European Union [Electronic Resource]. https://www.etf.europa.eu/en/news-and-events/news/ukraine-future-vision-vocatio nal-education

[28] Ofis from the Financial and Economic Analysis in Verkhovniy Radi Ukrainy. Expectations of the Dynamic of Depositors of Budget Budgets in 2016-2018.

https://feao.org.ua/products/local-deposits-2016-18/?Fbclid=IwAR0KhXwQBCG2 MmI6QmOzQ2-AiAdypbKJidHrhR-Yx0OmGyMreyPGx3PptK4

[29] Dzherelo: State Service of Analytics and Statistics of Ukraine, Given to Personnel and Information Agencies.

[30] Siverska, L.B. (2009) Realization of Conceptual Concepts in Ukraine in Ukraine through International Standards. News of the National Bank of Ukraine Help of the National Bank of Ukraine, 6, 182-185.

[31] Yu, V. Kovbasyuk, K.O. Vashchenko, Y. and Surmina, P. (2012) Sovereign Personnel Policy in Ukraine: Camp, Problems and Prospects for Development: Science. 